\title{
ESTIMATION OF SURFACE ROUGHNESS IN A SEMIARID REGION FROM C-BAND ERS-1 SYNTHETIC APERTURE RADAR DATA ${ }^{(1)}$
}

\author{
E. E. SANO(2), A. R. HUETE(3) \& M. S. MORAN ${ }^{(4)}$
}

\begin{abstract}
In this study, we investigated the feasibility of using the C-band E uropean Remote Sensing Satellite (ER S-1) synthetic aperture radar (SAR) data to estimate surface soil roughness in a semiarid rangeland. Radar backscattering coefficients were extracted from a dry and a wet season SAR image and were compared with 47 in situ soil roughness measurements obtained in the rocky soils of the Walnut Gulch Experimental Watershed, southeastern Arizona, USA. Both the dry and the wet season SAR data showed exponential relationships with root mean square (RMS) height measurements. The dry C-band ERS-1 SAR data were strongly correlated $\left(R^{2}=0.80\right)$, while the wet season SAR data have somewhat higher secondary variation $\left(R^{2}=0.59\right)$. This lower correlation was probably provoked by the stronger influence of soil moisture, which may not be negligible in the wet season SAR data. We concluded that the single configuration C-band SAR data is useful to esti mate surface roughness of rocky soils in a semi arid rangeland.
\end{abstract}

Index terms: surface roughness, radar remote sensing, microwave.

RESUMO: ESTIMATIVA DE RUGOSIDADE DE SOLO EM REGIÕES SEMI-ÁRIDAS POR MEIO DOS DADOS DE RADAR DE ABERTURA SINTÉTICA (BANDA C, SATÉLITE ERS-1)

Neste estudo, analisou-sea relação entre dados deradar deabertura sintética (banda C, satéliteE RS-1 - European RemoteSensing Satel lite) emedi das derugosi dadedo terreno numa regi ão semi-árida do Arizona, EUA. Os coeficientes deretroespal hamento obtidos de imagens das épocas seca e chuvosa foram comparados com 47 medi das de rugosidade do terreno obti das da M icrobacia do Wal nut Gulch, local izado no sudestedo estado do Arizona,

(1) Parte da Tese de PhD do primeiro autor, Universidade do Arizona, Tucson, AZ, USA.

(2) Pesquisador da E mbrapa, Caixa Postal 515, CEP 73301-970 Planaltina (DF) Brazil. E-mail: sano@cpac.embrapa.br.

(3) Professor da Universidade do Arizona, 429 Shantz BIdg no 38, Tucson, AZ, 85721, USA.

(4) Pesquisadora da USDA-SWRC, 2000 E. Rodovia Allen, Tucson, AZ, 85719, USA. 


\begin{abstract}
EUA. Foi observada correlação exponencial entre dados de radar da época seca emedidas de rugosi dade $\left(R^{2}=0,80\right)$. Com relação aos dados de radar da época chuvosa, também foi observada correlação exponencial, porém com dispersão mai or de pontos $\left(R^{2}=0,59\right)$. Esta correl ação mais baixa deveu-se, provavel mente, à maior influência da umidadede sol o nos processos de retroespal hamento na banda C, na época chuvosa. Os resultados deste experimento indicaram quedados deradar na banda $\mathrm{C}$ são promissores quantoà esti mativa derugosi dade de terreno em regiões semi-áridas.
\end{abstract}

Termos deindexação: rugosi dade do terreno, sensoriamento remoto por radar, microondas.

\section{INTRODUCTION}

One of the major goals in hydrology is to understand and quantify the processes that control hydrol ogic storages and fluxes at local, regional, and global scales (Moran et al., 1994). Soil roughness is one of the most important parameters in these hydrologic processes because it controls the distribution of rainfall into runoff, evapotranspiration and infiltration (Moore \& Larson, 1979; Dubois et al., 1995). In semiarid regions, soil roughness appears to play a major role for runoff forecasting on a watershed. For instance, at a field scale, roughness slows runoff down and traps water, which hel ps infiltration (Benallegue et al., 1995).

Measurements of soil roughness by conventional in situ methods such as the pin-based roughness meter developed by Simanton et al. (1978) or the ultrasonic profiler developed by Robichaud \& Molnau (1990) are labor intensive and essentially represent point-based information of a terrain. As a consequence, a number of remotely-sensed experiments have been conducted to estimate this parameter over large areas.

Experiments conducted using synthetic aperture radar (SAR) systems, which operate in the microwave spectral region (magnitude of wavelengths in centimeters) have shown a strong radar backscatter dependence on soil roughness (Ulaby et al., 1978; Moet al., 1988; Rao et al., 1993). These experiments havealso indicated a significant contribution from soil moisture and vegetation cover, suggesting the use of a multiplesensor configuration (combination of different frequencies, polarization, and incidence angles) to estimate soil roughness without ambiguity. Autret et al. (1989) found the following combination was the best for soil roughness estimation: multi-angle $\left(20\right.$ and $\left.40^{\circ}\right)$, low frequency (S- or C-band, 3.0 and $5.6 \mathrm{GHz}$, respectively), and $\mathrm{HH}$ polarization. Rao et al. (1993) reported that surface soil roughness could be estimated to an accuracy of $10 \%$ or better, if a three frequencies approach were used.

One of the problems in the estimation of soil roughness using multiple configurations is that none of the current satellite carrying SAR systems
(European Remote Sensing Satellite - ERS-1 and ERS-2; J apanese Earth Resource Satellite - J ERS1; and Canadian Remote Sensing Satellite RADARSAT) operates with multipleconfigurations. Thus, it is desirable to develop techniques using single band polarization to estimate soil roughness. Such techniques are most likely possiblefor semiarid regions because of the low soil moisture contents and sparse vegetation cover. The objectives of this study are (a) to investigate the potential use of existing C-band ERS-1 SAR system to estimate soil roughness in semiarid regions; and (b) to assess the effects of soil moisture on the soil roughness estimation.

\section{MATERIAL AND METHODS}

\section{Study area}

The study area is at the Walnut Gulch Experimental Watershed $\left(31.72^{\circ} \mathrm{N}\right.$ latitude, $110.00^{\circ} \mathrm{W}$ longitude), a semiarid rangeland near Tombstone, Arizona (Figure 1). This watershed, with approximately $150 \mathrm{~km}^{2}$, has been operated by the U.S. Department of Agriculture (USDA), Agricultural Research Service (ARS) since 1954. The vegetation is primarily desert shrubs and grasses, with shrubs being dominant in the western part, and grass in the eastern part of the watershed.

The main drainage of the study area runs from the nor theast to the southeast. The elevation ranges from about $1220 \mathrm{~m}$ (west part of the watershed) to $1890 \mathrm{~m}$ (east part of the watershed), where the topography becomes more dissecated. The watershed can be described as gently rolling hills incised by rather steep drainage channels, mainly at the east part of the watershed (Kustas et al., 1991).

The predominant textures of surfacesoils $(0-5 \mathrm{~cm})$ are sandy loams and gravelly loamy sands, with a small quantity of organic matter and a rock fraction around 30\% (Gel derman, 1970; Kustas \& Goodrich, 1994). Thetwo most dominant soil units in thestudy area are the Mabray-Chiricahua and the ForrestBonita soil complex units, covering about 13 and $9 \%$ of the watershed, respectively. The typical slope 


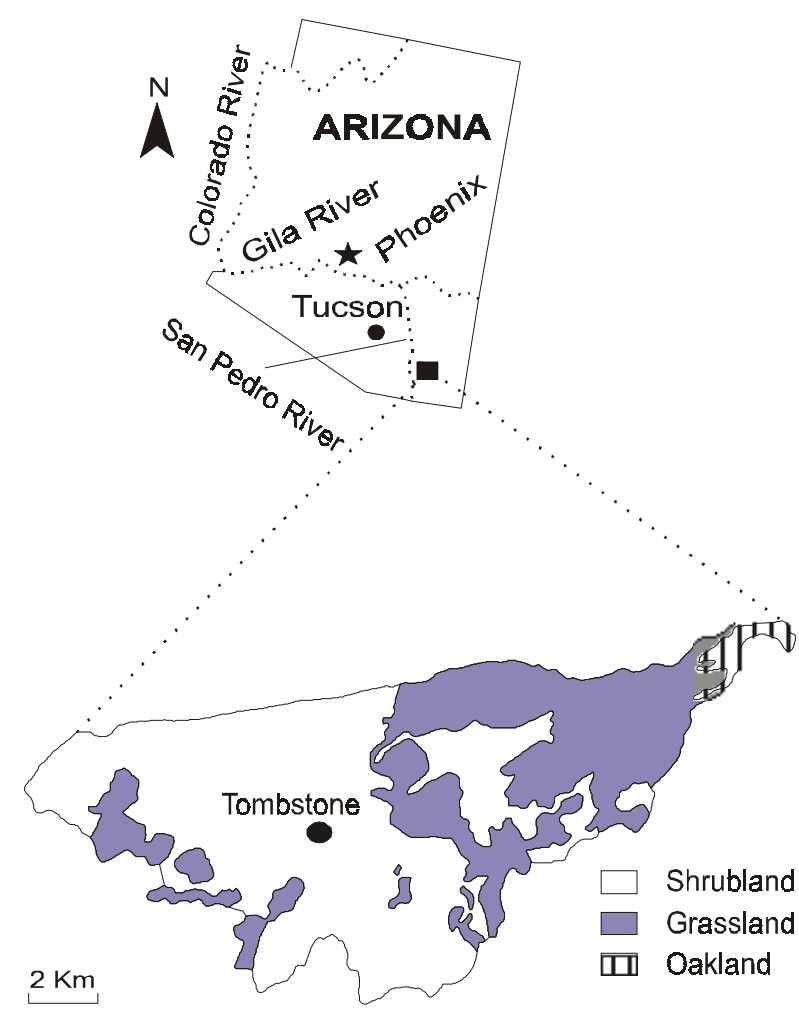

Figure 1. Map of the Walnut Gulch Experimental Watershed showing its geographical location in the State of Arizona.

range for Mabray-Chiricahua and Forrest-Bonita units are 3 to $15 \%$ and 0 to $3 \%$, respectively. The Mabray complex has a dark grayish brown color and very cobbly loam texture in the top $2 \mathrm{~cm}$ of soil surface and is classified as loamy-skeletal, carbonatic, thermic Lithic Ustic Torriorthent. The Chiricahua complex has a reddish brown col or, a very gravelly clay loam texture $(0-2 \mathrm{~cm})$ and is classified as dayey, mixed, thermic, shallow Ustollic Haplargid. The Forrest unit has a brown to dark brown color, fine sandy loam texture and is classified as a fine, mixed, thermicUstollic Hapargid. Finally, the Bonita unit has a grayish brown color, silt loam textureand is classified as a fine, montmorillonitic, thermic Typic Haplotorrert.

\section{Radar images}

This research was based on the analysis of an ERS-1 SAR image acquired on A pril 25, 1992 [Day of Year (DOY) 116] as part of the remote sensing project developed in 1992 over the Walnut Gulch Experimental Watershed (WG'92 experiment) (Moran et al., 1996). This date corresponded to a dry season, when the surface soil moisture was low and the vegetation was mostly dry. Samples of soil moisture obtained at four study sites in the watershed two days prior to the satellite overpass (DOY 114, 1992) indicated an averagevolumetric soil moisture content of $2.6 \%$. Therefore, we expect soil roughness to be the most dominant parameter in the backscattering process for this overpass. The SAR image was acquired at $5.3 \mathrm{GHz}$ (C-band), VV polarization, $23^{\circ}$ incidence angle, and $12.5 \mathrm{~m}$ pixel spacing.

Another ERS-1 SAR image was acquired in J uly 25, 1994 (DOY 206). This datecorresponded to a wet season, when the soil moisture content was high. About two thirds of the annual rainfall in the watershed occur in J uly and August as intensiveand convective thunderstorms. Rainfall records at 89 raingages located in the watershed indicated that the first storms related to the summer "monsoon" season of 1994 occurred on DOYs 204 and 205 and produced an average precipitation of $10.3 \mathrm{~mm}$ (standard deviation $=3.1 \mathrm{~mm}$ ). With the image acquired in this season, we expect to be able to evaluatethe effects of soil moisture on the estimation of soil roughness.

These two images were georeferenced to the Universal Transverse Mercator (UTM) coordinate system (Zone 12, 1927 North American Datum, Clarke 1866) and corrected for topographic effects. They were also corrected to account for the real backscattering area of each pixel, using a Digital Elevation Model (Beaudoin et al., 1994). Radar backscatter coefficients $\left(\sigma^{\circ}\right)$ were extracted from these preprocessed images using the following equation (Laur, 1992):

$$
\sigma^{\mathrm{o}}(\text { decibels, } \mathrm{dB})=10 \log \left(\overline{\mathrm{DN}}^{2}+\mathrm{STD}^{2}\right)-\mathrm{K}
$$

where

$\overline{\mathrm{DN}}=$ average digital number of each site (approximately 200 pixels per site);

STD = standard deviation; and

$\mathrm{K}$ = system calibration constant of the ERS-1 SAR system.

Bruniquel (1996) showed that the use of approximately 200 pixels can lead to $\sigma^{\circ}$ values with confidence interval smaller than $1 \mathrm{~dB}$. I $\mathrm{n}$ fact, all $\sigma^{\circ}$ calculations in this study presented confidence intervals smaller than $0.8 \mathrm{~dB}$.

\section{Field Measurements}

Height profiles of the soil surfaces were measured using a 1 m roughness meter devel oped by Simanton et al. (1978), which gives a profile of 100 heights of soil surface per meter. Twenty six study sites (Figure 2) were located in the grass-dominated, gravelly sandy loam soils of the watershed (Breckenfeld, 1993). Another 21 study sites were located at the shrub-dominated, very gravelly sandy loam soils in the western part of the watershed. 


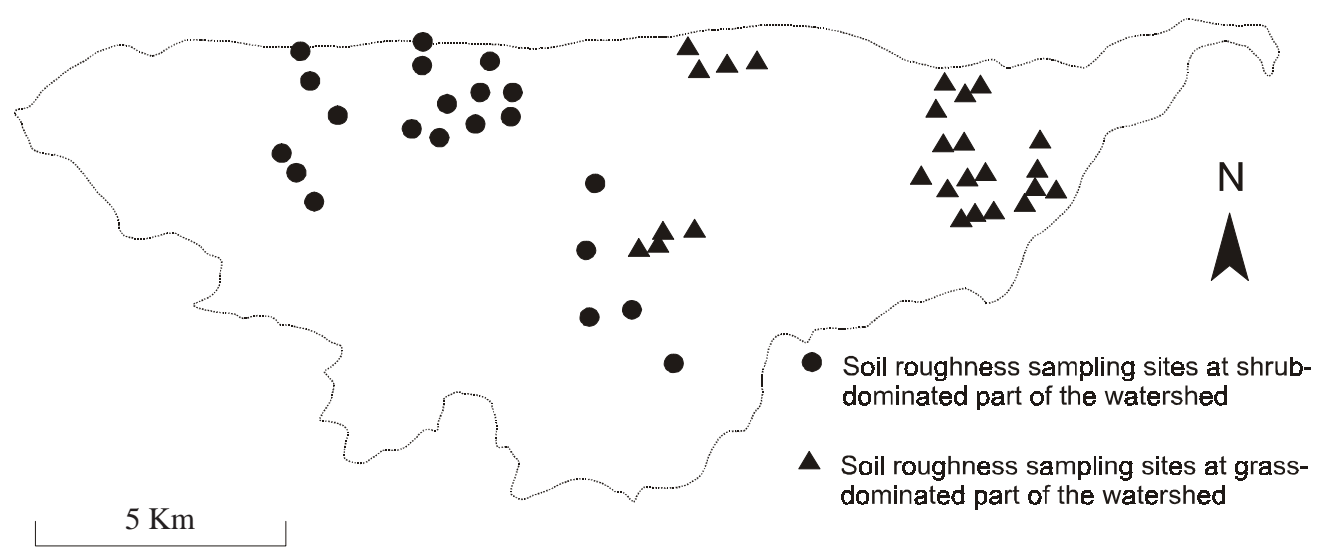

Figure 2. Walnut Gulch Experimental Watershed boundaries with location of soil moisture sampling sites.

Three plots, each having an area of $1 \times 2 \mathrm{~m}$, were randomly selected per site for the roughness measurements. The $1 \mathrm{~m}$ roughness meter (Figure 3 ) was paraleled approximately every $20 \mathrm{~cm}$ interval within each plot, giving 10 roughness profiles per plot or 3000 point readings per site. These point readings were connected to lines and digitized using a Geographical I nformation System software package (Arc/l nfo) to calculate the standard deviation (in centimeters). The average of 30 standard deviations (10 lines per pl ot $\times 3$ plots) corresponded to the roughness index or to the Root Mean Square (RMS) height variation of the site.

Thesoil roughness measurements were compared with dry and wet season SAR images. Because the soil roughness of the study area is determined basically by the presence of rock fragments in the surface, we assumed that this physical parameter did not change significantly over the time period between the two analyzed images. Unlike agricultural areas, surface roughness over natural environment in semiarid regions is quite stable.

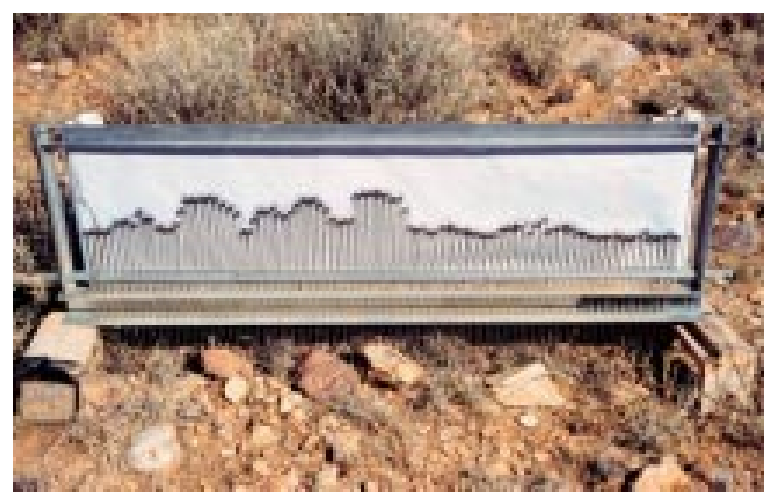

Figure 3. Illustration of field roughness measurement in the Walnut Gulch Watershed.

\section{RESULTS AND DISCUSSION}

Figure 4 shows the relation between the dry season C-band SAR data and RMS height measurements $(h)$ in the watershed. The $h$ values varied from 0.6 to $2.0 \mathrm{~cm}$; that is, a variation of approximately $1.4 \mathrm{~cm}$ in RMS height caused a $\sigma^{\circ}$ variation of approximately $2.5 \mathrm{~dB}$. The following general exponential relationship, including $h$ measurements from both grass- and shrubdominated part of the watershed, was obtained $\left(R^{2}=0.80\right.$, with a level of significance $\left.\alpha=0.05\right)$ :

$$
\sigma^{\circ}=8.48-8.71 e^{-1.96 h}
$$

This relation confirms a previous finding by Altese et al. (1996), who also found an exponential correlation between these two parameters. The exponential correlation indicates that the sensitivity of radar data to soil roughness is higher at lower roughness conditions. In other words, the retrieval of soil roughness from SAR data for relatively smooth surfaces appears to be more difficult because of the need for accurate roughness measurements in such smooth surfaces. As mentioned by Ulaby et al. (1978), an accurate field description of surface roughness of a soil medium is very difficult to obtain.

A decrease in this correlation can be expected when the RMS height measurements are compared with a wet season ERS-1 overpass. A stronger effect of soil moisture in the backscattering process is expected for wet season images, consequently decreasing the relation between SAR data and $h$ measurements. This stronger effect can be shown by plotting the radar signals from the wet season against the signals from the dry season image (Figure 5). Most of the points are located above the 1:1 line, indicating that the backscattering coefficients of the wet season are higher than those of dry season. The average difference variation of $\sigma^{\circ}$ between these two dates was $1.0 \mathrm{~dB}$ (maximum = $2.3 \mathrm{~dB}$ ) for grass-dominated sites and $1.2 \mathrm{~dB}$ 


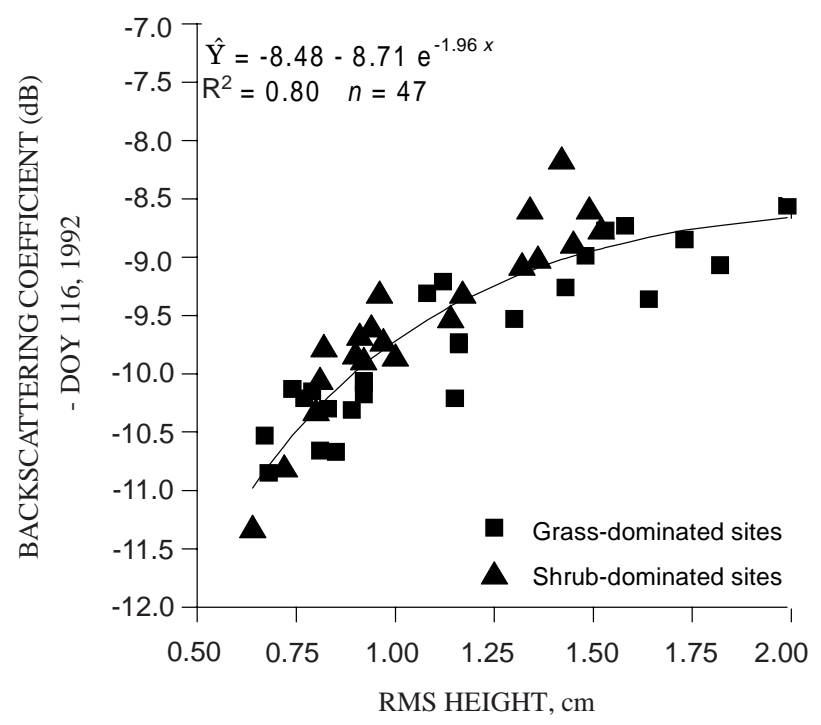

Figure 4. 1992 dry season backscattering coefficient dependence on soil roughness of the Walnut Gulch Experimental Watershed.

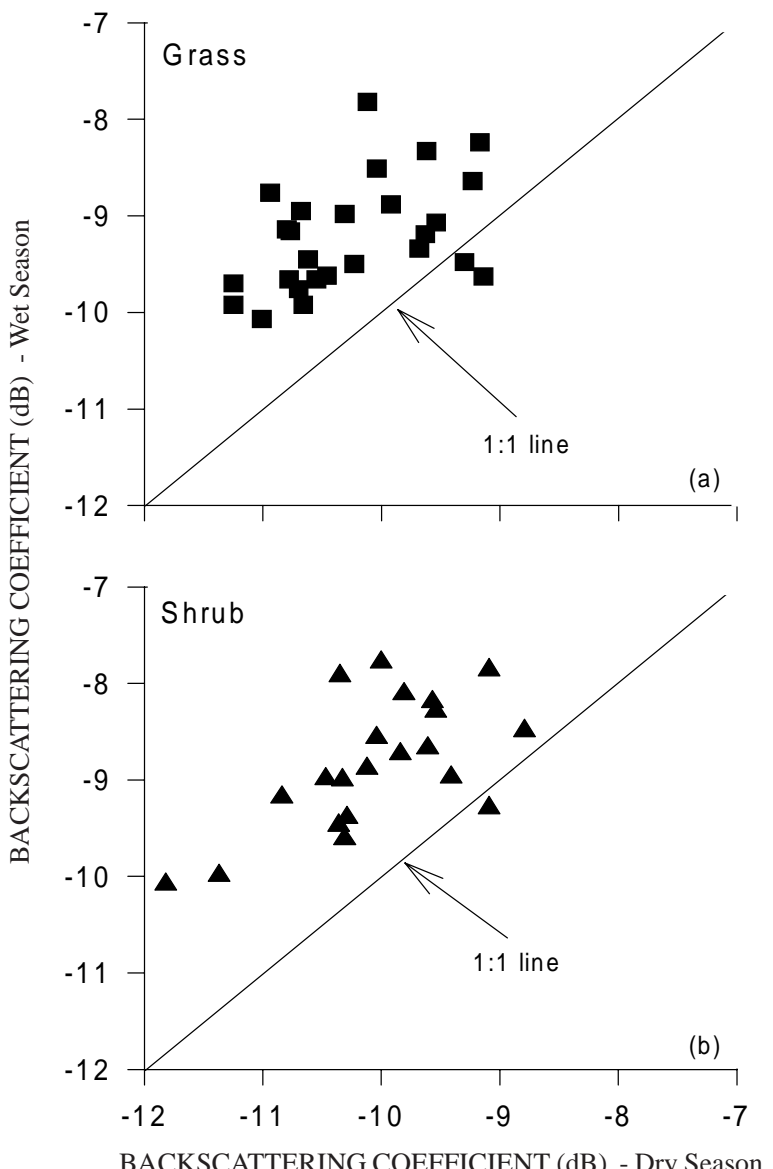

Figure 5. Relation between 1994 wet season SAR image and 1992 dry season SAR image for (a) grass-dominated and (b) shrub-dominated sites. (maximum $=2.4 \mathrm{~dB}$ ) for shrub-dominated sites, that is, about the same magnitude of $\sigma^{\circ}$ variation $(\sim 2.5 \mathrm{~dB})$ provoked by a $\mathrm{h}$ variation of $\sim 1.6 \mathrm{~cm}$, as stated before.

However, when the wet season C-band SAR data is compared with the RMS height measurements (Figure 6), the best-fit relation was still an exponential relation, although with a higher dispersion of points $\left(R^{2}=0.59\right)$. The exponential curve found for the dry season data was shifted up by $\sim 0.5 \mathrm{~dB}$. As expected, the increase in the backscattering coefficient was higher for sites having low RMS heights $\left(\Delta \sigma^{\circ} \sim 1 \mathrm{~dB}\right.$ at $\left.\mathrm{h}=0.6 \mathrm{~cm}\right)$ than for those with high RMS heights $\left(\Delta \sigma^{\circ} \sim 0.4 \mathrm{~dB}\right.$ at $\mathrm{h}=$ $1.75 \mathrm{~cm})$.

The dispersion of points was probably caused by the non-uniform variation of soil moisture in the watershed. Thehigh natural spatial variability of soil moisture is already well-known (Rao \& Ulaby, 1977).

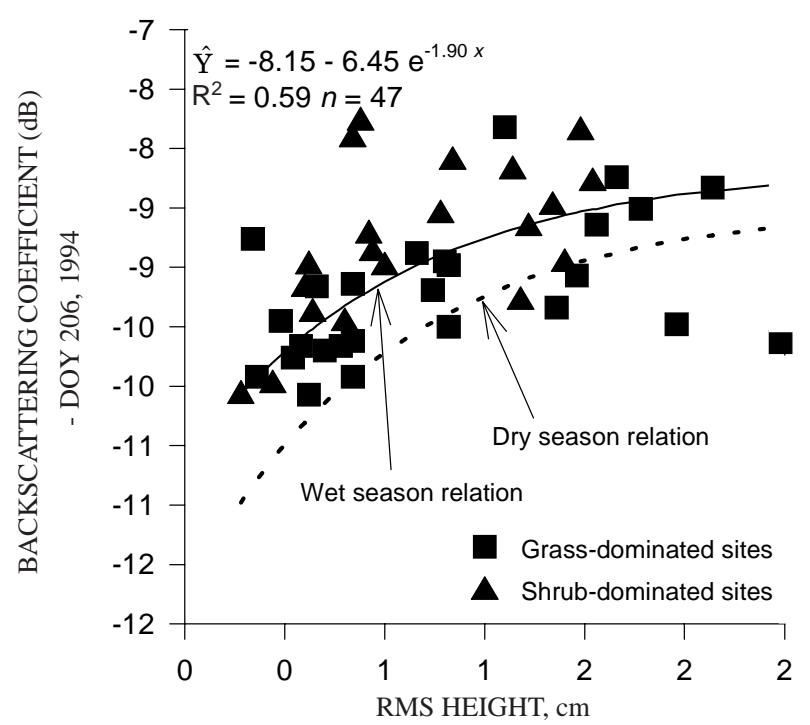

Figure 6. 1994 wet season backscattering coefficient dependence on soil roughness of the Walnut Gulch Experimental Watershed.

\section{CONCLUSIONS}

1. Dry season C-band SAR backscattering was found to be correlated with soil roughness measurements. An exponential correlation between these two parameters was obtained, with $\mathrm{R}^{2}=0.80$ $(\alpha=0.05)$, suggesting that C-band can besuccessfully used to retrieve surface roughness from rocky soils of semiarid regions.

2. Wet season C-band SAR data were also found to be exponentially correlated with soil roughness, although with a higher dispersion of points $\left(R^{2}=0.59\right)$. 
3. Thus, soil roughness retrieval from wet season C-band SAR data may be possible, but techniques to minimizethe effects of soil moisture need to beapplied.

4. The exponential relationship between $\sigma^{\circ}$ and $\mathrm{h}$ measurements indicates that if the soil surface is relatively smooth, accurate soil roughness measurements are required because of the high sensitivity of SAR data to the $h$ variations, that is, small variations in $\mathrm{h}$ can cause significant variations in $\sigma^{\circ}$.

\section{ACKNOWLEDGMENTS}

Special thanks are due to Dr. D. Goodrich for providing the orthophotos of the watershed, and R. Simanton for allowing the use of the roughness meter. Theassistance of personnel at theARS Walnut Gulch Experimental Watershed facility in Tombstone, AZ, was also very important. This work was partially supported by the NASA-EOS Interdisciplinary Research Program in Earth Sciences (NASA IDP-88-086), National Science Foundation grant (INT-9314872), and NASA Landsat Team grant (\#S-41396-F).

\section{LITERATURE CITED}

ALTESE, E.; BOLOGNANI, O.; MANCINI, M. \& TROCH, P.A. Retrieving soil moisture over bare soil from ERS 1 synthetic aperture radar data: sensitivity analysis based on a theoretical surface scattering model and field data. Water R. Res., 32:653-661, 1996.

AUTRET, M.; BERNARD, R. \& VIDAL-MADJ AR, D. Theoretical study of the sensitivity of the microwave backscattering coefficient to the soil surface parameters. Int. J . Remote Sens., 10:171-179, 1989.

BEAUDOIN, A.; DESHAYES, M.; PIET, L.; STUSSI, N. \& Le TOAN, T. Retrieval and analysis of temperate forest backscatter signatures from multitemporal ERS-1 data over hilly terrain. In: SYMPOSIUM OF ERS-1 PILOT PROJ ECT, 1., Toledo, 1994. Proceedings. Toledo, European Space Agency, 1994. p.283-289.

BENALLEGUE, M.; TACONET, O.; VIDAL-MADJ AR, D. \& NORMAND, M. The use of radar backscattering signals for measuring soil moisture and surface roughness. Remote Sens. Environ., 53:61-68, 1995.

BRECKENFELD, D.H. Soil survey of Walnut Gulch Experimental Watershed, Arizona, Soil Conservation Service, USDA, 1993. 130p.

BRUNIQUEL, J . Contributions de données multi-temporelles a I'amelioration radiometriques et a l'utilisation d'images de radar a synthese d'ouverture. Toulouse, Université Paul Sabatier, 1996. (Tese de Doutorado)

DUBOIS, P.C.; van ZYL, J . \& ENGMAN, T. Measuring soil moisture with imaging radars. IEEE Trans. Geosci. Remote Sens., 33:915-926, 1995.
GELDERMAN, F.W. Soil survey of Walnut Gulch experimental watershed, Arizona, report, Soil Conserv. Serv. Agric. Res. Serv., USDA, 1970.

KUSTAS, W.P.; GOODRICH, D.C.; MORAN, M.S.; AMER, S.A.; BACH, L.B.; BLANFORD, J.H.; CHEHBOUNI, A.; CLAASSEN, H.; CLEMENTS, W.E.; DORAISWAMY,P.C.; DUBOIS, P.; CLARKE, T.R.; DAUGHTRY, C.S.T.; GELLMAN, D.I .; GRANT, T.A.; HIPPS, L.E.; HUETE, A.R.; HUMES, K.S.; J ACKSON, T.J .; KEEFER, T.O.; NICHOLS, W.D.; PARRY, R.; PERRY, E.M.; PINKER, R.T.; PINTER J r., P.J .; QI , J .; RIGGS, A.C.; SCHUMGGE, T.J .; SHUTKO, A.M.; STANNARD, D.I.; SWIATEK, E.; van LEEUWEN, J .D.; van ZYL, J .; VIDAL, A.; WASHBURNE, J \& \& WELTZ, M.A. An interdisciplinary field study of the energy and water fluxes in the atmosphere-biosphere system over semiarid rangelands: description and some preliminary results. Bull. Am. Meteor. Soc. 72:1683-1698, 1991.

KUSTAS, W.P. \& GOODRICH, D.C. Preface. Water R. Res., 30:1211-1225, 1994

LAUR, H. Derivation of backscattering coefficients $\sigma^{\circ}$. ERS-1 SAR. Neville, France, PRI Products, European Space Agency Publication, 1992.

MO, T.; WANG, J .R. \& SCHMUGGE, T.J . Estimation of surface roughness parameters from dual-frequency measurements of radar backscattering coefficients. IEEE Trans. Geosci. Remote Sens., 26:575-580, 1988.

MOORE, I.D. \& LARSON, C.L. Estimating micro-relief surface storage from point data. Trans. Am. Soc. Agric. Eng., 5:10731077, 1979.

MORAN, M.S.; CLARKE, T.R.; KUSTAS, W.P.; WELTZ, M. \& AMER, S.A. Evaluation of hydrologic parameters in a semiarid rangeland using remotely sensed spectral data. Water R. Res., 30:1287-1297, 1994.

MORAN, M.S., RAHMAN, A.F.; WASHBURNE,J .C.; GOODRICH, D.C.; WELTZ, M.A. \& KUSTAS, W.P. Combining the Penman-M onteith equation with measurements of surface temperature and reflectance to estimate evaporation rates of semiarid grassland. Agr. For. Meteor., 80:87-109, 1996.

RAO, R.G.S. \& ULABY, F.T. Optimal sampling techniques for ground truth data in microwave remote sensing of soil moisture. Remote Sens. Environ., 6:289-301, 1977.

RAO, K.J .; RAJ U, S. \& WANG, J .R. Estimation of soil moisture and surface roughness parameters from backscattering coefficient. IEEE Trans. Geosci. Remote Sens., 31:10941099, 1993.

ROBICHAUD, P.R. \& MOLNAU, M. Measuring soil roughness changes with an ultrasonic profiler. Trans. Am. Soc. Agric. Eng., 33:1851-1858, 1990.

SIMANTON, J.R.; DIXON, R.M. \& MCGOWAN, I. A microroughness meter for evaluating rainwater infiltration. In: HYDROLOGY AND WATER RESOURCES IN ARIZONA AND THE SOUTHWEST, 8., Flagstaff, AZ, April 14-15. Proceedings. Flagstaff, 1978. p.171-174.

ULABY, F.T.; BATLIVALA, P.P. \& DOBSON, M.C. Microwave backscatter dependence on surface roughness, soil moisture, and soil texture. Part I - bare soil. IEEE Trans. Geosci. Electronics, 16:286-295, 1978 